\title{
PACS1 wt Allele
}

National Cancer Institute

\section{Source}

National Cancer Institute. PACS1 wt Allele. NCI Thesaurus. Code C114564.

Human PACS1 wild-type allele is located within 11q13.1-q13.2 and is approximately 174 $\mathrm{kb}$ in length. This allele, which encodes phosphofurin acidic cluster sorting protein 1, plays a role in targeting proteins to the Golgi. Mutation of the gene is associated with autosomal dominant mental retardation 17. 